\title{
Analisis Kepuasan Pengguna Website SMK Negeri 2 Palembang Menggunakan Regresi Linear Berganda
}

\author{
Eka Hartati, Ria Indriyani, Indah Trianingsih
}

Sekolah Tinggi Manajemen Informatika dan Komputer Palcomtech, Indonesia

\section{Article Info}

Article history:

Received, 29 April 2020

Revised, 20 August 2020

Accepted, 27 August 2020

\section{Kata Kunci:}

Kepuasan Pengguna

Regresi Linear Berganda

Website

Informasi

Variabel

\begin{abstract}
ABSTRAK
Website merupakan salah satu alat yang dirasa cocok untuk membantu memenuhi kebutuhan informasi akademis termasuk SMK Negeri 2 Palembang salah satu peranan pihak sekolah sebagai media sumber informasi dan pendidikan dimana yang menjadi informasi resmi bagi program atau informasi yang ingin disampaikan. SMK Negeri 2 Palembang. SMK Negeri 2 Palembang memiliki situs website resmi dengan alamat http://smkn2palembang.sch.id/ sebagai sarana menginformasikan kepada guru, siswa dan siswi, Bagaimana mengukur dan menganalisa kualitas website SMK Negeri 2 Palembang berdasarkan model kualitas kepuasan pengguna (user satisfaction) yang terdiri dari variabel ease of use, customization, download delay dan content. Jumlah sampel dalam penelitian ini sebanyak 363 responden yang terdiri dari guru, pegawai dan siswa, teknik pengumpulan data dalam penelitian ini menggunakan kuesioner yang disebarkan secara langsung ke responden. Berdasarkan hasil uji regresi linier menunjukkan bahwa nilai koefisien regresi untuk keempat variabel yaitu ease of use, customization, download delay dan content bernilai positif berarti bahwa jika nilai keempat variabel semakin baik, maka kepuasan pengguna akan meningkat.

\section{ABSTRACT}

The website is one of the tool that is considered suitable to help meet the needs of academic information including SMK Negeri 2 Palembang one of the role of the school as a source of information and education media which becomes the official information for the program or information that wants to be conveyed. SMK Negeri 2 Palembang. SMK Negeri 2 Palembang has an official website with the address http://smkn2palembang.sch.id/ as a means of informing teachers, students and students, how to measure and analyze the quality of SMK Negeri 2 Palembang website based on a model of user satisfaction quality consisting of variables ease of use, customization, download delay and content. The sample count in this study was 363 respondents consisting of teachers, employees and students, data collection techniques in this study using questionnaires distributed directly to respondents. Based on the results of linear regression test shows that the value of the regression coefficient for all four variables namely ease of use, customization, download delay and content is positive value means that if the value of the four variables is better then user satisfaction will increase.
\end{abstract}

This is an open access article under the CC BY-SA license.

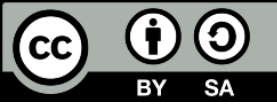

\section{Penulis Korespondensi:}

Eka Hartati,

Program Studi Sistem Informasi,

Sekolah Tinggi Manajemen Informatika dan Komputer Palcomtech.

Email: eka_hartati@palcomtech.ac.id 


\section{PENDAHULUAN}

Perkembangan teknologi informasi yang demikian pesat memberikan dampak pada perubahan layanan organisasi ataupun perusahaan. Saat ini layanan kepada pengguna juga dapat dilakukan secara online. Website adalah suatu aplikasi yang berisikan dokumen multimedia (terdiri dari teks, gambar, animasi, suara dan video) yang di dalamnya menggunakan protokol HTTP dan untuk mengaksesnya menggunakan sebuah perangkat lunak yang disebut dengan browser [1]. Website merupakan kumpulan dari halaman-halaman web yang berhubungan dengan file-file yang terkait [2]. Website pada umumnya dapat digunakan dalam melakukan penyimpanan, mampu menampilkan informasi yang dianggap penting, serta sangat berkaitan terhadap organisasi ataupun perusahaan yang menggunakan arsitektur client atau server. Website sendiri berisikan perpaduan antara teks, suara, hypermedia dan grafis. Website dapat digunakan melakukan hubungan dengan sumbernya dalam jarak jauh dan menggunakan antarmuka grafis untuk pengguna supaya penampilnnya menarik.

Peranan website sudah menjadi bagian yang penting dari suatu organisasi ataupun akademis termasuk SMK Negeri 2 Palembang. Salah satu peranan pihak sekolah sebagai media sumber informasi dan pendidik dimana yang menjadi informasi resmi bagi program atau informasi yang ingin disampaikan pihak sekolah kepada siswa seperti mengenai informasi portal berita, sekolah via online, kegiatan serta pelayanan akademik pada tiap siswa-siswi SMK Negeri 2 Palembang.

SMK Negeri 2 Palembang merupakan salah satu sekolah menengah kejuruan yang ada di Kota Palembang terus berupaya meningkatkan jumlah siswa baru setiap tahunnya. Dengan banyaknya jumlah pendaftar atau calon siswa menunjukkan kualitas suatu sekolah agar dapat bersaing dengan sekolah negeri maupun swasta lainnya yang ada di Kota Palembang. SMK Negeri 2 Palembang memiliki situs website resmi dengan alamat http://smkn2palembang.sch.id/ sebagai sarana menginformasikan kepada guru, siswa dan siswi. Saat ini website SMK Negeri 2 Palembang belum pernah dilakukan pengukuran dan analisis. Penelitian yang dilakukan oleh Ni Made Sri Rukmiyati dan I ketut Budiartha pada tahun 2016 dengan judul "Pengaruh Kualitas Sistem Informasi, Kualitas Informasi dan Perceived Usefulness" pada kepuasan pengguna akhir software akuntansi (studi empiris pada hotel berbintang di provinsi bali) dengan hasil penelitian semakin baik kualitas sistem informasi, kualitas informasi, dan perceived usefulness maka akan meningkatkan kepuasan pengguna akhir software akuntansi. Pada penelitian ini peneliti melakukan analisis dengan menggunakan model kualitas kepuasan pengguna Green and Person yang terdiri dari empat variabel. Adapun variabel bebas yang digunakan dalam penelitian ini adalah ease of use, customization, download delay dan content dan variabel terikat menggunakan user satisfaction [3] . Analisis yang digunakan dalam penelitian ini menggunakan analisis regresi linier berganda dimana untuk mencari tahu apakah variabel ease of use, customization, download delay dan content berpengaruh terhadap variabel user satisfaction. Tujuan dari penelitian ini untuk menganalisis kepuasan pengguna website SMK Negeri 2 dengan menggunakan model Green and Pearson.

\section{METODE PENELITIAN}

Penelitian ini terdiri dari tahapan yang merupakan urutan sistematis dalam sebuah penelitian. Adapun alur penelitian ini ditunjukkan pada Gambar 1. Adapun penjelasan dari alur penelitian adalah sebagai berikut:

1. Rumusan masalah, mengukur dan menganalisa kualitas website SMK Negeri 2 Palembang berdasarkan model kualitas kepuasan pengguna Green and Person [4].

2. Melakukan observasi dan studi pustaka. Observasi merupakan teknik pengumpulaan data secara langsung dengan mengamati operasi maupun prosedur yang berlaku pada objek penelitian [4]. Observasi dan studi pustaka dilakukan untuk mencari, mempelajari serta mengumpulkan informasi dari penelitian terdahulu serta membaca artikel yang mengenai objek permasalahan yang akan dibahas, dalam hal ini mengenai kepuasan terhadap pengguna website.

3. Implementasi dari website SMK Negeri 2 Palembang dengan menggunakan alat ukur model kepuasaan pengguna ada 4 variabel yaitu: ease ofuse, costumization, download delay dan content. Agar suatu variabel dapat diukur, maka variabel tersebut harus dioperasionalkan [5].

4. Alat ukur yang digunakan adalah kuesioner yang memiliki data ordinal dan bentuk skala pengukuran menggunakan skala likert.

5. Kuesioner merupakan alat pengumpulan data primer dengan menggunakan metode survei untuk mendapatkan opini responden [6]. Kuesioner disebarkan kepada responden kemudian hasil dari kuesioner dikumpulkan kembali. 
6. Analisis kepuasaan pengguna menggunakan metode regresi linear berganda dengn SPSS 2.1

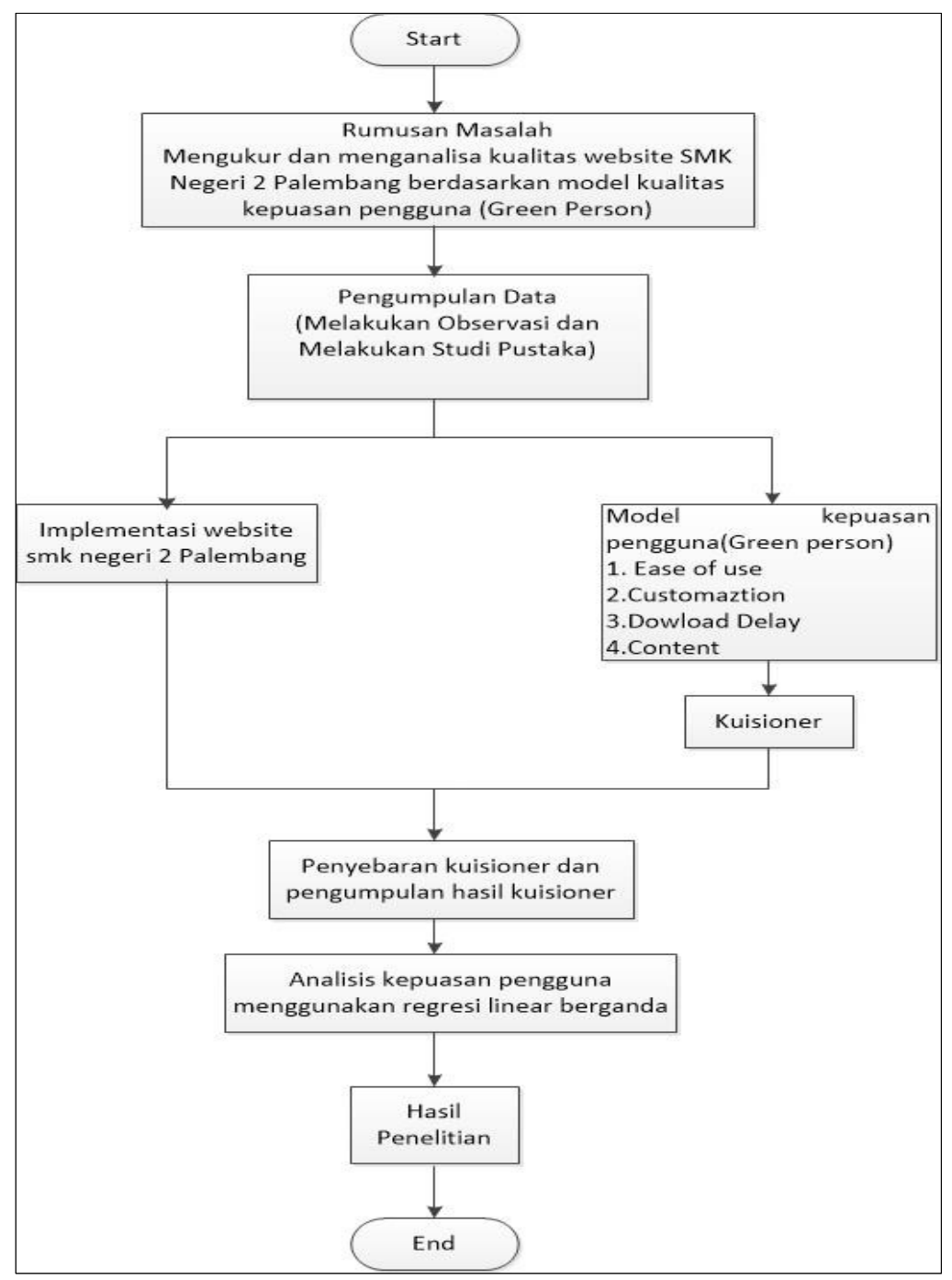

Gambar 1. Alur penelitian

Kepuasan pelanggan ditentukan oleh persepsi dari pelanggan terhadap performansi produk ataupun jasa dalam memenuhi harapan pelanggan. Pelanggan merasa puas jika harapan pelanggan terpenuhi [7]. Green and Pearson merumuskan empat variabel terbaik dalam melakukan pengukuran kepuasan pengguna terhdap website, yaitu ease of use/ease of navigation, customization, download delay, content [8]. Model penelitian yang digunakan diperlihatkan pada Gambar 2.

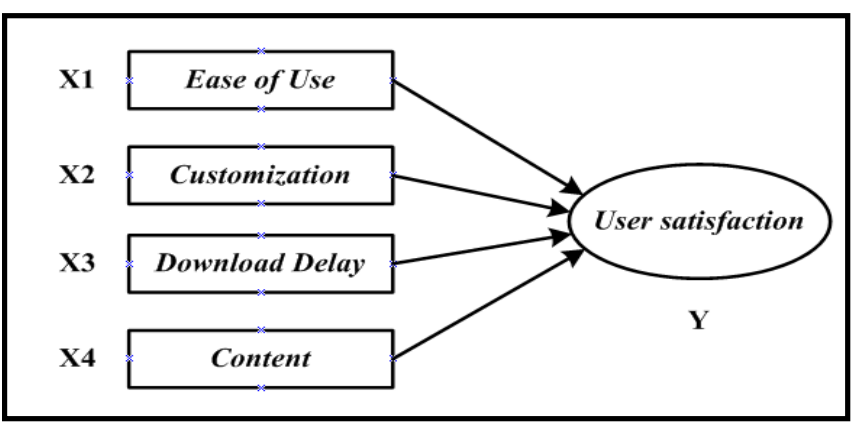

Gambar 2.Model penelitian

\section{HASIL DAN ANALISIS}

Penelitian yang dilakukan oleh peneliti menggunakan analisis deskriptif guna untuk mengetahui karakteristik dari responden. Responden yang terlibat terdiri dari guru, siswa dan pegawai SMK Negeri 2 
Palembang yang mempunyai karakteristik masing-masing. Berikut ini merupakan distribusi responden berdasarkan status atau kelompok yang bisa dilihat pada Gambar 3.

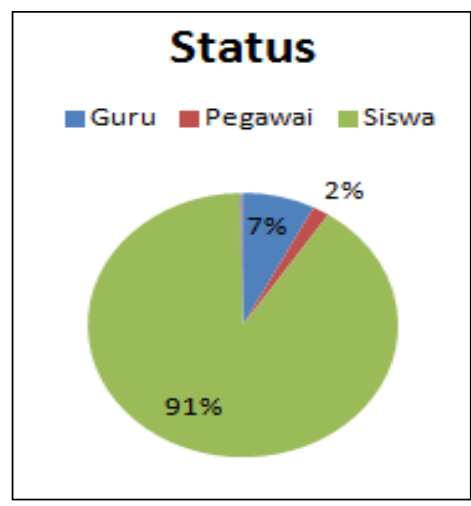

Gambar 3. Distribusi responden

Dengan menggunakan teknik pengambilan sampel proportionate stratified random sampling maka proporsi sampel yang ditentukan berdasarkan persepsi peneliti proportionate stratified random sampling adalah teknik menentukan sample bila populasi mempunyai anggota yang berstrata secara proporsional [ㅁ] . Proporsi responden dapat dilihat pada Tabel 1.

Tabel 1. Proporsi Responden

\begin{tabular}{cc}
\hline Responden & Jumlah Sampel \\
\hline Guru & $196: 2613 \times 400=30$ \\
Pegawai & $45: 2613 \times 400=7$ \\
Siswa & $2373: 2613 \times 400=363$ \\
\hline
\end{tabular}

Berdasarkan Tabel 1 didapatkan bahwa pengguna dari website sebagian besar adalah siswa dengan jumlah sampel yang ditentukan sebesar 363 orang, guru dengan jumlah sampel yang ditentukan sebesar 30 orang dan jumlah sampel yang ditentukan untuk pegawai sebesar 7 orang. Untuk setiap kelompok responden memiliki karakteristik masing-masing. Karakteristik responden jika dilihat berdasarkan jenis kelamin diperlihatkan pada Gambar 4.Berdasarkan Gambar 4 jenis kelamin laki-laki sebesar 67\% dan perempuan sebesar 33\%.

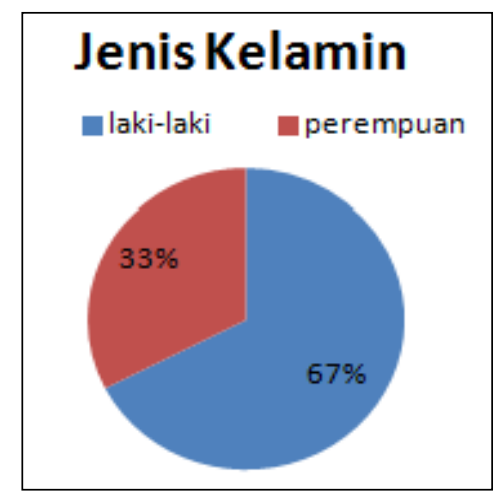

Gambar 4.Karakteristik responden berdasarkan jenis kelamin

Definisi variabel untuk penelitian ini disajikan dalam Tabel 2.Penelitian ini menggunakan anaslisis regresi berganda yang terdiri dari variabel yang berpengaruh dan variabel yang dipengaruhi, yaitu variabel bebas $\left(X_{l}\right.$, $\left.X_{2}, X_{3}, X_{4}\right)$ dan satu variabel terikat $(Y)$. Berikut ini definisi variabel peneliian yang dapat dilihat pada Tabel 2. 
Tabel 2.Definisi variabel penelitian

\begin{tabular}{|c|c|c|}
\hline Variabel & Indikator & Kode \\
\hline $\begin{array}{l}\text { Kemudahan (Ease } \\
\text { Of Use) }\end{array}$ & $\begin{array}{l}\text { Apakah website ini mudah untuk anda akses? } \\
\text { Apakah tidak sulit mencari informasi yang anda butuhkan didalam website ini? } \\
\text { Apakah menu dalam website ini mudah digunakan? }\end{array}$ & $\mathrm{X} 1$ \\
\hline $\begin{array}{l}\text { Personalisasi } \\
\text { (Customization) }\end{array}$ & $\begin{array}{l}\text { Apakah tampilan warna pada website ini menarik? } \\
\text { Apakah teks pada website dapat dibaca dengan mudah? } \\
\text { Apakah tampilan website ini mudah di kenali? }\end{array}$ & $\mathrm{X} 2$ \\
\hline $\begin{array}{l}\text { Kecepatan Akses } \\
\text { Padar Aplkasi } \\
(\text { Download Delay) }\end{array}$ & $\begin{array}{l}\text { Apakah halaman website ini tampil dengan cepat anda mengkilik link-nya? } \\
\text { Apakah anda mudah mengakses informasi disetiap halaman? } \\
\text { Apakah informasi yang ada di website ini mudah didownload? } \\
\text { Apakah saat anda mendownload informasi pada website ini harus membutuhkan waktu lama? }\end{array}$ & $\mathrm{X} 3$ \\
\hline $\begin{array}{l}\text { Penyajian Informasi } \\
\text { (Content) }\end{array}$ & $\begin{array}{l}\text { Apakah informasi yang disajikan sesuai dengan kebutuhan anda? } \\
\text { Apakah gambar yang ditampilkan dalam website ini dapat dilihat dengan jelas? } \\
\text { Apakah kalimat Informasi yang disajikan mudah dimengerti? }\end{array}$ & $\mathrm{X} 4$ \\
\hline $\begin{array}{l}\text { Kepuasan Pengguna } \\
\text { (User Satisfaction) }\end{array}$ & $\begin{array}{l}\text { Apakah anda puas dengan layanan yang ada pada website SMK Negeri } 2 \text { Palembang? } \\
\text { Apakah website ini selalu memberikan informasi yang update? } \\
\text { Apakah anda puas saat melihat website ini melalui gadge? }\end{array}$ & $\mathrm{Y}$ \\
\hline
\end{tabular}

Uji validitas dilakukan untuk menguji apakah instrumen yang digunakan, dalam hal ini angket memenuhi persyaratan validitas dengan menggunakan korelasi Pearson [9]. Uji ini digunakan untuk mengetahui layak atau tidaknya setiap pertanyaan atau pernyataan yang digunakan. Berikut ini merupakan uji validitas kuisioner. Tabel hasil pengujian validitas kuisioner disajikan pada Tabel 3.

Tabel 3.Hasil Uji Validitas Kuisioner

\begin{tabular}{cccccc}
\hline Variabel & $\begin{array}{c}\text { Item } \\
\text { Pertanyaan }\end{array}$ & R-Tabel & R-Hitung & Hasil & Keterangan \\
\hline Ease of Use $\left(X_{1}\right)$ & Item 1 & 0,08 &, 402 & $\mathrm{R}$ hitung $>\mathrm{r}$ tabel & Valid \\
& Item 2 & 0,08 &, 383 & $\mathrm{R}$ hitung $>\mathrm{r}$ tabel & Valid \\
& Item 3 & 0,08 &, 425 & $\mathrm{R}$ hitung $>\mathrm{r}$ tabel & Valid \\
Customization $\left(X_{2}\right)$ & Item 4 & 0,08 &, 321 & $\mathrm{R}$ hitung $>\mathrm{r}$ tabel & Valid \\
& Item 5 & 0,08 &, 334 & $\mathrm{R}$ hitung $>\mathrm{r}$ tabel & Valid \\
& Item 6 & 0,08 &, 542 & $\mathrm{R}$ hitung $>\mathrm{r}$ tabel & Valid \\
Download delay $\left(X_{3}\right)$ & Item 7 & 0,08 &, 420 & $\mathrm{R}$ hitung $>\mathrm{r}$ tabel & Valid \\
& Item 8 & 0,08 &, 443 & $\mathrm{R}$ hitung $>\mathrm{r}$ tabel & Valid \\
& Item 9 & 0,08 &, 423 & $\mathrm{R}$ hitung $>\mathrm{r}$ tabel & Valid \\
& Item 10 & 0,08 &, 491 & $\mathrm{R}$ hitung $>\mathrm{r}$ tabel & Valid \\
Content $\left(X_{4}\right)$ & Item 11 & 0,08 &, 221 & $\mathrm{R}$ hitung $>\mathrm{r}$ tabel & Valid \\
& Item 12 & 0,08 &, 383 & $\mathrm{R}$ hitung $>\mathrm{r}$ tabel & Valid \\
& Item 13 & 0,08 &, 387 & $\mathrm{R}$ hitung $>\mathrm{r}$ tabel & Valid \\
User Satisfaction $(Y)$ & Item 14 & 0,08 &, 328 & $\mathrm{R}$ hitung $>\mathrm{r}$ tabel & Valid \\
& Item 15 & 0,08 &, 434 & $\mathrm{R}$ hitung $>\mathrm{r}$ tabel & Valid \\
& Item 16 & 0,08 &, 491 & $\mathrm{R}$ hitung $>\mathrm{r}$ tabel & Valid \\
\hline
\end{tabular}

Dari Tabel 3 diatas dapat diketahui bahwa seluruh pertanyaan yang terdiri dari 16 pertanyaan dinyatakan valid, hal ini dikarenakan semua nilai dari $r$ hitung lebih besar dari nilai $r$ tabel. Pada penelitian ini reliablity statistic dapat dilihat pada tabel 4.

Tabel 4.Reliability Statistic

\begin{tabular}{cc}
\hline Cronbachs Alpha & Nof Items \\
\hline 0,801 & 16 \\
\hline
\end{tabular}

Uji reliabilitas bertujuan untuk mengukur konsisten atau tidaknya suatu jawaban seseorang terhadap item pertanyaan didalam sebuah kuisioner. Suatu konstruk atau variabel dikatakan reliabel jika memberikan nilai $\alpha$ $>0,60[\underline{10}]$. Berikut ini uji reabilitas hasil kuesioner dapat dilihat pada Tabel 5. 
Tabel 5.Uji Reliabilitas Hasil Kuesioner

\begin{tabular}{lcl}
\hline \multicolumn{1}{c}{ Variabel } & Cronbach Alpha & Keterangan \\
\hline Ease of Use $\left(X_{1}\right)$ & 0,600 & Cukup Reliable \\
Customization $\left(X_{2}\right)$ & 0,455 & Cukup Reliable \\
Download Delay $\left(X_{3}\right)$ & 0,497 & Cukup Reliable \\
Content $\left(X_{4}\right)$ & 0,395 & Agak Reliable \\
User Satisfaction $(\mathrm{Y})$ & 0,484 & Cukup Reliable \\
\hline
\end{tabular}

Pengujian reliabilitas hasil kuisioner yang disajikan pada Tabel 5 menunjukkan bahwa nilai cronbach alpha pada variabel $X_{1}, X_{2}, X_{3}$ dan $Y$ pertanyaan nilainya berada diantara 0,41-0,60 maka item pertanyaan tersebut dinyatakan cukup reliable. Pada variabel $X_{4}$ pertanyaan nilainya berada diantara 0,21-0,40 maka item pertanyaan tersebut dinyatakan agak reliable.

Uji Normalitas merupakan pengujian yang dilakukan dengan tujuan untuk menilai sebaran data pada sebuah kelompok data atau variabel, apakah data tersebut tersebar secara normal atau tidak. Uji normalitas digunakan untuk menentukan data yang telah dikumpulkan berdistribusi normal atau diambil dari populasi normal [11]. Berikut ini hasil uji normalitas yang dapat dilihat pada Tabel 6.

Tabel 6. Uji Normalitas

\begin{tabular}{ccccccc}
\hline & \multicolumn{3}{c}{ Kolmogorov-Smirnov } & \multicolumn{3}{c}{ Shapiro-Wilk } \\
\cline { 2 - 7 } & Statistic & df & Sig. & Statistic & df & Sig. \\
\hline Normalitas &, 084 & 400 &, 000 &, 988 & 400 &, 003 \\
\hline
\end{tabular}

Uji linearitas (lilliefors significance correction) digunakan untuk mengetahui hubungan antar variabel, yaitu variabel bebas dan variabel terikat yang dimana apakah bersifat linier atau tidak. Pengujian ini menggunakan uji-F [12]. Penilaian uji linieritas yaitu dapat dilihat dengan membandingkan antara $c$ hitung dan $c$ tabel apabila nilai $c$ hitung $<c$ tabel, maka variabel tersebut dikatakan linier. Grafik normal Q-Q plot of normalitas dapat di lihat pada Gambar 5.

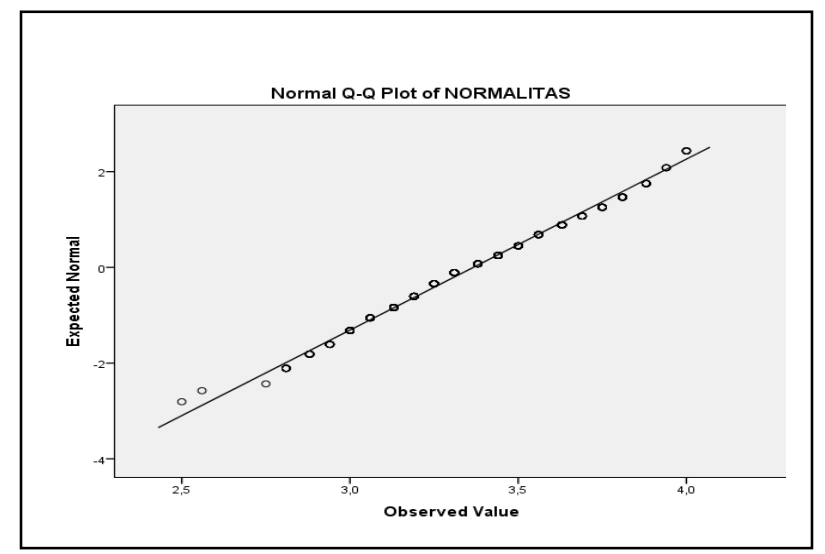

Gambar 5.Grafik normal Q-Q plot of normalitas

Berdasarkan hasil pengolahan data, diperoleh hasil pengujian linearitas data untuk pernyataan pada variabel ease of use $\left(X_{1}\right)$ dengan user satisfaction $(Y)$, cuztomization $\left(X_{2}\right)$ dengan user satisfaction $(Y)$, download delay $\left(X_{3}\right)$ dengan user satisfaction $(Y)$, content $\left(X_{4}\right)$ dengan user satisfaction $(Y)$. Hasil Uji linearitas dapat dilihat pada Tabel 7, 8, 9, dan 10.

Tabel 7.Tabel Anova Y terhadap X1

\begin{tabular}{|c|c|c|c|c|c|c|c|}
\hline & & & $\begin{array}{r}\text { Sum of } \\
\text { Squares }\end{array}$ & df & $\begin{array}{c}\text { Mean } \\
\text { Square }\end{array}$ & $\mathbf{F}$ & Sig. \\
\hline \multirow[t]{5}{*}{$Y \times X_{1}$} & Between & (Combined) & 17.875 & 5 & 3.575 & 34.169 & .000 \\
\hline & \multirow[t]{2}{*}{ Groups } & Linearity & 17.112 & 1 & 17.112 & 163.551 & .000 \\
\hline & & $\begin{array}{c}\text { Deviation } \\
\text { from Linearity }\end{array}$ & .763 & 4 & .191 & 1.824 & .123 \\
\hline & \multirow{2}{*}{\multicolumn{2}{|c|}{ Within Groups }} & 41.223 & 394 & .105 & & \\
\hline & & & 59.099 & 399 & & & \\
\hline
\end{tabular}


Tabel 8.Tabel Anova Y terhadap X2

\begin{tabular}{|c|c|c|c|c|c|c|c|}
\hline & & & $\begin{array}{c}\text { Sum of } \\
\text { Squares }\end{array}$ & df & $\begin{array}{c}\text { Mean } \\
\text { Square }\end{array}$ & $\mathbf{F}$ & Sig. \\
\hline \multirow[t]{4}{*}{$Y \times X_{2}$} & Between & (Combined) & 9.643 & 6 & 1.607 & 12.771 & .000 \\
\hline & Groups & Linearity & 8.943 & 1 & 8.943 & 71.064 & .000 \\
\hline & \multirow{2}{*}{\multicolumn{2}{|c|}{$\begin{array}{c}\text { Within Groups } \\
\text { Total }\end{array}$}} & 49.456 & 393 & .126 & & \\
\hline & & & 59.099 & 399 & & & \\
\hline
\end{tabular}

Tabel 9.Tabel Anova Y terhadap X3

\begin{tabular}{|c|c|c|c|c|c|c|c|}
\hline & & & $\begin{array}{c}\text { Sum of } \\
\text { Squares }\end{array}$ & df & $\begin{array}{c}\text { Mean } \\
\text { Square }\end{array}$ & $\mathbf{F}$ & Sig. \\
\hline \multirow{4}{*}{$Y \times X_{3}$} & Between & (Combined) & 13.750 & 7 & 1.964 & 16.979 & .000 \\
\hline & Groups & Linearity & 12.555 & 1 & 12.555 & 108.522 & .000 \\
\hline & \multirow{2}{*}{\multicolumn{2}{|c|}{ Within Groups }} & 45.349 & 392 & .116 & & \\
\hline & & & 59.099 & 399 & & & \\
\hline
\end{tabular}

Tabel 10.Tabel Anova Y terhadap X4

\begin{tabular}{|c|c|c|c|c|c|c|c|}
\hline & & & $\begin{array}{c}\text { Sum of } \\
\text { Squares }\end{array}$ & df & $\begin{array}{c}\text { Mean } \\
\text { Square }\end{array}$ & $\mathbf{F}$ & Sig. \\
\hline \multirow[t]{4}{*}{$Y \times X_{4}$} & Between & (Combined) & 4.759 & 4 & 1.190 & 8.648 & .000 \\
\hline & Groups & Linearity & 4.120 & 1 & 4.120 & 29.947 & .000 \\
\hline & \multicolumn{2}{|c|}{ Within Groups } & 54.340 & 395 & .138 & & \\
\hline & \multicolumn{2}{|c|}{ Total } & 59.099 & 399 & & & \\
\hline
\end{tabular}

\subsection{Uji Korelasi Pearson}

Hasil pengujian uji korelasi dapat dilihat pada Tabel 11.

Tabel 11.Hasil Uji Korelasi

\begin{tabular}{|c|c|c|c|c|c|c|}
\hline & & $\mathrm{X} 1$ & $\mathbf{X 2}$ & $\mathbf{X 3}$ & $\mathrm{X} 4$ & $\mathbf{Y}$ \\
\hline \multirow[t]{3}{*}{$X_{I}$} & Pearson Correlation & 1.000 & $402 * *$ & ,420** & ,340** & ,538 \\
\hline & Sig. (2-tailed) & &, 000 &, 000 & 000 &, 000 \\
\hline & $\mathrm{N}$ & 400 & 400 & 400 & 400 & 400 \\
\hline \multirow[t]{3}{*}{$X_{2}$} & Pearson Correlation & $402 * *$ & 1.000 &, $548 * *$ &, $287 * *$ &, $389 * *$ \\
\hline & Sig. (2-tailed) &, 000 & &, 000 &, 000 &, 000 \\
\hline & $\mathrm{N}$ & 400 & 400 & 400 & 400 & 400 \\
\hline \multirow[t]{3}{*}{$X_{3}$} & Pearson Correlation & $420 * *$ &, $548 * *$ & 1.000 & $470 * *$ & $461 * *$ \\
\hline & Sig. (2-tailed) &, 000 &, 000 & &, 000 &, 001 \\
\hline & $\mathrm{N}$ & 400 & 400 & 400 & 400 & 400 \\
\hline \multirow[t]{3}{*}{$X_{4}$} & Pearson Correlation &, $340 * *$ &, $287 * *$ & $470 * *$ & 1.000 &, $264 * *$ \\
\hline & Sig. (2-tailed) &, 000 &, 000 &, 000 & &, 000 \\
\hline & $\mathrm{N}$ & 400 & 400 & 400 & 400 & 400 \\
\hline \multirow[t]{3}{*}{$Y$} & Pearson Correlation &, $538 * *$ &, $389 * *$ & $461 * *$ &, $264 * *$ & 1.000 \\
\hline & Sig. (2-tailed) &, 000 &, 000 &, 001 &, 000 & \\
\hline & $\mathrm{N}$ & 400 & 400 & 400 & 400 & 400 \\
\hline
\end{tabular}

1. Variabel ease of use dengan variabel user satisfaction memperoleh nilai sig. $0,000<0,05$ maka $H_{0}$ ditolak dan $H_{a}$ diterima

2. Variabel customization dengan variabel user satisfaction memperoleh nilai sig. $0,000<0,05$ maka $H_{o}$ ditolak dan $H_{a}$ diterima

3. Variabel download delay dengan variabel user satisfaction memperoleh nilai sig. 0,000<0,05 maka $H_{o}$ ditolak dan $H_{a}$ diterima

4. Variabel content dengan variabel user satisfaction memperoleh nilai sig. $0,000<0,05$ maka $H_{o}$ ditolak dan $H_{a}$ diterima. 


\subsection{Regresi Linier Berganda}

Regresi linier berganda merupakan sebuah analisis yang menjelaskan hubungan antara variabel dependen dengan faktor-faktor yang mempengaruhi lebih dari satu variabel indenpenden [13]. Regresi linier berganda digunakan untuk mencari tahu apakah variabel ease of use, customization, download delay dan content berpengaruh terhadap variabel user satisfaction, yang berarti terdapat empat variabel $X$ dan satu variabel $Y$ user satisfaction. Peneliti menggunakan regresi linier berganda, karena dengan menggunakan regresi linier berganda peneliti dapat menganalisis menggunakan beberapa variabel bebas $(X)$ terhadap variabel terikat $(Y)$. Persamaan yang digunakan untuk menghitung regresi linier berganda menggunakan persamaan (1).

$$
Y=a+b_{1} X_{1}+b_{2} X_{2}+b_{3} X_{3}+b_{4} X_{4}+e
$$

Keterangan:

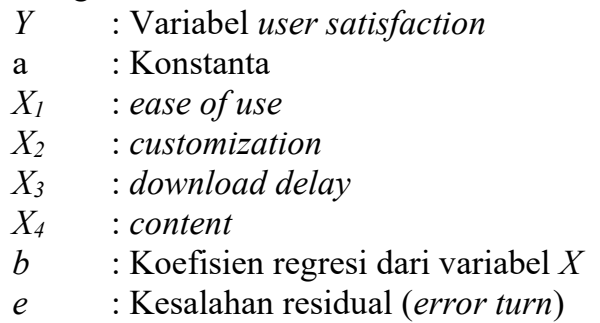

\subsection{Uji-F (Secara Simultan)}

Pengujian hipotesa Uji-F dalam penelitian ini secara simultan dimaksudkan untuk mengukur besarnya pengaruh variabel bebas yaitu, ease of use $\left(X_{1}\right)$, coztumization $\left(X_{2}\right)$, download delay $\left(X_{3}\right)$, dan content $\left(X_{4}\right)$ yaitu secara simultan (bersama) terhadap variabel terikat yaitu user satisfaction $(Y)$ [14]. Hasil uji-F dapat dilihat pada Tabel 12.

Pengajuan hipotesis dalam Uji F yaitu:

$\mathrm{H}_{0}$ : Variabel $X_{1}, X_{2}, X_{3}, X_{4}$ berpengaruh secara simultan dan signifikan terhadap variabel $Y$.

$\mathrm{H}_{\mathrm{a}}$ : Variabel $X_{1}, X_{2}, X_{3}, X_{4}$ tidak berpengaruh secara simultan dan signifikan terhadap variabel $Y$.

Hipotesa pengujian Uji-F:

$\mathrm{H}_{\mathrm{o}}$ : Variabel bebas yaitu ease of use, coztumization, download delay, dan content tidak berpengaruh secara simultan dengan variabel terikat yaitu user satisfaction.

$\mathrm{H}_{\mathrm{a}}$ :Variabel bebas yaitu ease of use, coztumization, download delay, dan content berpengaruh secara simultan dengan variabel terikat yaitu user satisfaction.

Dengan keputusan :

Jika nilai Sig $>0.05$ maka $\mathrm{H}_{\mathrm{o}}$ diterima $\mathrm{H}_{\mathrm{a}}$ ditolak

Jika nilai $\mathrm{Sig}<0.05$ maka $\mathrm{H}_{\mathrm{o}}$ ditolak $\mathrm{H}_{\mathrm{a}}$ diterima

Tabel 12.Hasil Uji - F ANOVA ${ }^{\mathrm{a}}\left(\right.$ Variabel $X_{1}, X_{2}, X_{3}, X_{4}$ dengan Y)

\begin{tabular}{cccccc}
\hline Model & Sum of Squares & Df & Mean Squares & F & Sig \\
\hline Regression & 21.456 & 4 & 5.364 & 56.285 & .000 \\
Residual & 37.643 & 395 & .095 & & \\
Total & 59.099 & 399 & & & \\
\hline
\end{tabular}

Keterangan:

1. Dependent variable: $Y$

2. Predictors: (constant), $X_{4}, X_{2}, X_{1}, X_{3}$

Berdasarkan tabel hasil uji-F Diperoleh nilai signifikansi sebesar 0,000 dimana nilai sig. $0,000<0,05$ maka dapat disimpulkan bahwa $\mathrm{H}_{\mathrm{o}}$ ditolak dan $\mathrm{H}_{\mathrm{a}}$ diterima yang berarti bahwa ada pengaruh secara simultan antara variabel bebas yang terdiri dari ease of use, customization, download delay dan content secara bersamasama (simultan) terhadap user satisfaction.

\subsection{Uji-T (Secara Parsial)}

Uji-T berpasangan (paired t-test) adalah salah satu metode pengujian hipotesis dimana data yang digunakan berpasangan [15]. Uji-T dilakukan untuk melihat apakah masing-masing variabel independen berpengaruh 
terhadap variabel dependen. Uji-T pada dasarnya menunjukkan secara jauh pengaruh satu variabel penjelas atau independen dalam menerangkan variasi variabel dependen [16]. Hasil uji T dapat dilihat pada Tabel 13.

Uji-T digunakan untuk mengukur signifikansi pengaruh pengambilan keputusan dilakukan berdasarkan perbandingan nilai thitung masing-masing koefisien regresi dengan ttabel (nilai kritis) dengan tingkat signifikansi $(\alpha) 5 \%$ dengan derajat kebebasan $\mathrm{df}=n-1$.

Pengajuan hipotesis dalam Uji T yaitu:

$\mathrm{H}_{\mathrm{o}}$ : Variabel $X$ berpengaruh secara signifikan terhadap variabel $Y$.

$\mathrm{H}_{\mathrm{a}}$ : Variabel $X$ tidak berpengaruh secara signifikan terhadap variabel $Y$.

Pengujian hipotesis parsial dilakukan dengan beberapa kriteria. Kriteria pengujian yang dimaksud yaitu:

Jika thitung $>$ ttabel, atau pvalue $<\alpha=0,05$ maka $\mathrm{H}_{\mathrm{o}}$ ditolak dan $\mathrm{H}_{\mathrm{a}}$ diterima berarti variabel independen mempunyai pengaruh signifikan terhadap variabel dependen.

Jika thitung $<$ tabel, atau pvalue $>\alpha=0,05$ maka $\mathrm{H}_{\mathrm{o}}$ diterima dan $\mathrm{H}_{\mathrm{a}}$ tidak diterima berarti variabel independen mempunyai pengaruh tidak signifikan terhadap variabel dependen.

Tabel 13.Hasil Uji - T Coefficients $\mathrm{a}\left(X_{1}, X_{2}, X_{3}, X_{4}\right.$ dan $\left.Y\right)$

\begin{tabular}{|c|c|c|c|c|c|c|}
\hline \multirow{2}{*}{\multicolumn{2}{|c|}{ Model }} & \multicolumn{2}{|c|}{ Unstandardized Coefficients } & \multirow{2}{*}{$\begin{array}{c}\text { Standardized Coefficients } \\
\text { Beta } \\
\end{array}$} & \multirow[t]{2}{*}{$\mathbf{T}$} & \multirow[t]{2}{*}{ Sig. } \\
\hline & & B & Std. Error & & & \\
\hline \multirow{5}{*}{1} & (Constant) & .962 & .185 & & 5.211 & .000 \\
\hline & $\mathrm{x} 1$ & .377 & .043 & .401 & 8.693 & .000 \\
\hline & $\mathrm{x} 2$ & .088 & .045 & .097 & 1.975 & .049 \\
\hline & $\mathrm{x} 3$ & .274 & .059 & .247 & 4.653 & .000 \\
\hline & $\mathrm{x} 4$ & -.017 & .050 & -.016 & -.348 & .728 \\
\hline
\end{tabular}

Keterangan: Dependent Variable: $Y$

Berdasarkan tabel 11. hasil uji-Korelasi :

1. Variabel ease of use $\left(\mathrm{X}_{1}\right)$

$\mathrm{H}_{\mathrm{o}}$ : variabel ease of use tidak berpengaruh secara parsial dengan variabel user satisfaction.

$\mathrm{Ha}$ : variabel ease of use berpengaruh secara parsial dengan variabel user satisfaction.

Diperoleh nilai signifikansi sebesar 0,00 dimana nilai sig. 0,00<0,05 maka dapat disimpulkan bahwa Ha diterima dan Ho ditolak yang berarti bahwa ada pengaruh secara parsial antara variabel ease of use terhadap variabel user satisfaction.

2. Variabel customization $\left(X_{2}\right)$

$\mathrm{H}_{\mathrm{o}}$ : variabel customization tidak berpengaruh secara parsial dengan variabel user satisfaction.

Ha : variabel customization berpengaruh secara parsial dengan variabel user satisfaction.

Diperoleh nilai signifikansi sebesar 0,049, dimana nilai sig.0,49<0,05 maka dapat disimpulkan bahwa $\mathrm{H}_{\mathrm{a}}$ diterima dan $\mathrm{H}_{\mathrm{o}}$ ditolak yang berarti bahwa ada pengaruh secara parsial antara variabel customization terhadap variabel user satisfaction.

3. Variabel download delay $\left(X_{3}\right)$

$\mathrm{H}_{\mathrm{o}}$ : variabel download delay tidak berpengaruh secara parsial dengan variabel user satisfaction.

$\mathrm{H}_{\mathrm{a}}$ : variabel download delay berpengaruh secara parsial dengan variabel user satisfaction.

Diperoleh nilai signifikansi sebesar 0,000 dimana nilai sig. 0,000<0,05 maka dapat disimpulkan bahwa $\mathrm{H}_{\mathrm{a}}$ diterima dan $\mathrm{H}_{\mathrm{o}}$ ditolak yang berarti bahwa ada pengaruh secara parsial antara variabel download delay terhadap variabel user satisfaction.

4. Variabel content $\left(X_{4}\right)$

$\mathrm{H}_{\mathrm{o}}$ : variabel content tidak berpengaruh secara parsial dengan variabel user satisfaction.

$\mathrm{H}_{\mathrm{a}}$ : variabel content berpengaruh secara parsial dengan variabel user satisfaction.

Diperoleh nilai signifikansi sebesar 0,074, dimana nilai sig. 0,728 >0,05 maka dapat disimpulkan bahwa $\mathrm{H}_{\mathrm{a}}$ ditolak dan $\mathrm{H}_{\mathrm{o}}$ diterima yang berarti bahwa tidak ada pengaruh secara parsial antara variabel content terhadap variabel user satisfaction 


\section{KESIMPULAN}

Berdasarkan hasil analisis tingkat kepuasan terhadap website SMK Negeri 2 Palembang, maka dapat ditarik kesimpulan hasil penilaian pengguna website SMK Negeri 2 Palembang. Pada Variabel ease of use pada indikator pengaksesan Website SMK Negeri 2 Palembang mendapatkan nilai tertinggi sebesar 85,62\%, artinya responden sangat puas bahwa website SMK Negeri 2 Palembang mudah untuk di akses. Variabel customization pada indikator teks yang ada pada website SMK Negeri 2 Palembang dapat dibaca dengan mudah mendapatkan nilai tertinggi sebesar 85,56\%, artinya responden puas dengan teks yang ada pada website SMK Negeri 2 Palembang karena dapat dibaca dengan mudah. Pada variabel download delay pada indikator informasi yang dibutuhkan website SMK Negeri 2 Palembang mudah didownload mendapatkan nilai sebesar $86,06 \%$ artinya responden sangat puas dengan informasi yang dapat didownload pada website SMK Negeri 2 Palembang. Variabel content pada indikator gambar yang ditampilkan di SMK Negeri 2 Palembang bisa dilihat dengan jelas mendapatkan nilai tertinggi sebesar $86,93 \%$, artinya responden puas dengan penyajian informasi pada SMK Negeri 2 Palembang. Pada variabel satisfaction, indikator "secara keseluruhan, apakah anda merasa puas dengan pelayanan yang ada pada website SMK Negeri 2 Palembang" mendapatkan nilai tertinggi sebesar $85,87 \%$ artinya responden puas atas pelayanan yang diberikan SMK Negeri 2 Palembang.

Dari hasil interpretasi maka dapat disimpulkan bahwa nilai yang tertinggi berjumlah sebesar $86,93 \%$ yang terdapat pada variabel content dan nilai terendah sebesar $59,18 \%$ yang terdapat pada variabel user satisfaction. Berdasarkan hasil uji regresi linier menunjukkan bahwa nilai koefisien regresi untuk ke empat variabel yaitu ease of use, customization, download delay dan content bernilai positif berarti bahwa jika nilai keempat variabel semakin baik, maka kepuasan kepuasan pengguna akan meningkat. Akan tetapi berdasarkan ujiT menunjukkan bahwa hanya variabel ease of use, customization dan download delay yang berpengaruh secara signifikan terhadap variabel user satisfaction sedangkan variabel content tidak berpengaruh terhadap user satisfaction.

\section{UCAPAN TERIMA KASIH}

Ucapan terima kasih penulis sampaikan kepada Pihak SMK Negeri 2 Palembang yang telah memberikan izin riset. Penulis ucapkan juga kepada kedua orang tua yang telah memberikan dukungan moril terhadap penelitian ini serta kepada teman-teman dosen yang telah membagikan ilmu kepada peneliti.

\section{REFERENSI}

[1] M. Suhartanto, "Pembuatan Website Sekolah Menengah Pertama Negeri 3 Delanggu dengan Menggunakan php dan MySQL,” Journal Speed - Sentra Penelitian Engineering dan Edukasi, vol. 4, no. 1, pp. 1-8, 2012.

[2] D. E. Hendrianto, "Pembuatan Sistem Informasi Perpustakaan Berbasis Website pada SMPN 1 Donorojo Kabupaten Pacitan," Indonesian Journal of Networking and Security, vol. 3, no. 4, pp. 5764, 2014.

[3] D. I. Sensuse and S. H. Prayoga, "Analisis Usability Pada Aplikasi Berbasis Web dengan Mengadopsi Model Kepuasan Pengguna (User Satisfaction),” Jurnal Sistem Informasi, vol. 6, no. 1, pp. 70-79, 2010.

[4] R. D. Risanty and A. Sopiyan, "Pembuatan Aplikasi Kuesioner Evaluasi Belajar Mengajar Menggunakan Bot Telegram Pada Fakultas Teknik Universitas Muhammadiyah Jakarta (FT-UMJ) dengan Metode Polling," in Seminar Nasional Sains dan Teknologi, 2017, no. November, pp. 1-9.

[5] F. R. Putra, H. N. Utami, and M. S. Hakam, "Pengaruh Lingkungan Kerja Terhadap Kinerja (Studi Pada Karyawan PT. Naraya Telematika Malang)," Jurnal Administrasi Bisnis, vol. 6, no. 1, pp. 1-8, 2013.

[6] I. N. S. Wahyu Wijaya and K. J. Atmaja, "Pengembangan Sistem Evaluasi Kinerja Dosen (EKuesioner) STMIK STIKOM Indonesia,” Jurnal Sains dan Teknologi, vol. 8, no. 1, p. 55, 2019.

[7] A. Tahendrika, "Pengguna Motor Suzuki pada Bengkel PT Sinar Galesong Pratama Makassar," Jurnal Ekonomi, Manajemen dan Perbankan, vol. 1, no. 3, pp. 85-99, 2015.

[8] F. Fellasari and Y. I. Lestari, "Hubungan Antara Pola Asuh Orangtua Dengan Kematangan Emosi Remaja," Jurnal Psikologi, vol. 12, no. 2, p. 84, 2016.

[9] S. R. Sanusi, "Beberapa Uji Validitas dan Reliabilitas pada Instrumen Penelitian," Repository Universitas Sumatera Utara. pp. 113-116, 2010.

[10] A. A. Gunawan and H. P. Sunardi, "Pengaruh Kompensasi dan Disiplin Kerja Terhadap Kinerja Karyawan Pada PT. Gesit Nusa Tangguh,” Ilmiah Manajemen Bisnis, vol. 16, no. 1, pp. 1-12, 2016.

[11] D. Fahmeyzan, S. Soraya, and D. Etmy, "Uji Normalitas Data Omzet Bulanan Pelaku Ekonomi Mikro Desa Senggigi dengan Menggunakan Skewness dan Kurtosi," Jurnal Varian, vol. 2, no. 1, pp. 31-36, 2018. 
[12] S. P. Dewi, "Pengaruh Pengendalian Internal dan Gaya Kepemimpinan Terhadap Kinerja Karyawan SPBU Yogyakarta (Studi Kasus pada SPBU Anak Cabang Perusahaan RB.Group)," Nominal, Barometer Riset Akuntansi dan Manajemen, vol. 1, no. 1, 2012.

[13] E. Triyanto, H. Sismoro, and A. D. Laksito, "Implementasi Algoritma Regresi Linear Berganda untuk Memprediksi Produksi Padi di Kabupaten Bantul," Rabit: Jurnal Teknologi dan Sistem Informasi Univrab, vol. 4, no. 2, pp. 66-75, 2019.

[14] Triyanto_Evan, "Ervan Triyanto, 2) Heri Sismoro, 3) Arif Dwi Laksito,” vol. 4, no. 2, pp. 73-86, 2019.

[15] C. Montolalu and Y. Langi, "Pengaruh Pelatihan Dasar Komputer dan Teknologi Informasi bagi GuruGuru dengan Uji-T Berpasangan (Paired Sample T-Test)," d'Cartesian: Jurnal Matematika dan Aplikasi, vol. 7, no. 1, p. 44, 2018.

[16] D. Ariani and B. M. Dwiyanto, "Analisis Pengaruh Supply Chain Management Terhadap Kinerja Perusahaan (Studi pada Industri Kecil dan Menengah Makanan Olahan Khas Padang Sumatera Barat)," Jurnal Studi Manajemen Organisasi, vol. 10, no. 2, pp. 30-39, 2013. 
